\title{
AVALIAÇÃO DO USO DE ESGOTO TRATADO NA PRODUÇÃO DE PISOS
}

\author{
Ana E. S. Amaral (IC), Adriano L. Tonetti (PQ)
}

\section{Resumo}

Este trabalho fez parte de um projeto de pesquisa que visa o desenvolvimento de processos e técnicas em saneamento e a minimização do uso da água. Para isso, o esgoto tratado por um sistema simplificado foi usado na fabricação de peças de concreto para pavimentação. O efluente gerado em uma ETE composta por tanque séptico, filtro anaeróbio e filtro de areia foi empregado durante a produção de concreto, a fim de se estudar a influência desse parâmetro na qualidade final das peças, as quais foram avaliadas conforme a NBR 15900:2009 e a NBR $9781: 2013^{2}$. Não foram encontradas diferenças estatísticas significativas entre as resistências mecânicas à compressão das amostras fabricadas com água potável e com água de reúso, sugerindo a viabilidade do aproveitamento de esgoto tratado em atividades relacionadas à construção civil.

Palavras Chave: Esgoto, reúso, produção de pisos.

\section{Introdução}

Pesquisas desenvolvidas na FEC/UNICAMP demonstram que o uso de filtros anaeróbios com recheio de cascas de coco, combinados a filtros de areia, é extremamente viável e adequado para tratar o esgoto de pequenos povoamentos ou de pequenas indústrias ${ }^{3,4}$. Tal associação gera um efluente com DBO máxima ${ }^{4}$ de $30 \mathrm{mgL}^{-1}$, apontando a possibilidade de uso na irrigação agrícola ou na construção civil ${ }^{5,6}$.

O objetivo do trabalho foi analisar a viabilidade do emprego de água de reúso na construção civil, através da comparação de amostras de pisos de concreto, fabricados com água potável e com água de reuso, quanto à resistência mecânica.

\section{Resultados e Discussão}

A concentração de nitratos do efluente tratado estava dentro dos limites da NBR 15900:2009. Os valores de $\mathrm{pH}$ e da concentração de sólidos totais respeitavam os valores para água potável da Portaria $^{7} \mathrm{n}^{\circ}$ 2914. De acordo com a Resolução $\mathrm{n}^{8}$ 357, os valores de $\mathrm{pH}$, turbidez e coliformes enquadravam-se nos padrões para águas de Classe 1 e o valor de OD, na Classe 3.

Após a desinfecção por cloração, o efluente teve valores de coliformes e E. coli dentro da categoria excelente, segundo a classificação feita para águas destinadas à balneabilidade, da Resolução ${ }^{9}$ no 274 .

Seis corpos de prova prismáticos fabricados com água de reúso e seis fabricados com água potável foram ensaiados com a idade de sete e de 28 dias. Os dados obtidos nos ensaios passaram por análise de variância (ANOVA) através do software BioEstat 5.3.

Como a resistência à compressão de cada amostra podia variar, era essencial um teste estatístico. Comparar os valores médios poderia sugerir diferença entre os tipos de composição, mesmo que a diferença estivesse dentro das variabilidades intrínsecas aos dados experimentais ${ }^{10}$. Os testes indicaram, para um intervalo de confiança de $95 \%$, que não há diferença estatística significativa entre os pisos em relação à resistência à compressão.

\section{Conclusões}

Segundo os resultados, não há prejuízo quanto à resistência à compressão ao se utilizar esgoto tratado na fabricação de pisos intertravados de concreto. A água de reúso, além de apresentar características físicas e químicas compatíveis às admitidas pela NBR 15900:2009, resulta em peças de concreto cuja resistência mecânica à compressão não difere da resistência mecânica de peças fabricadas com água potável.

No contexto atual de escassez hídrica, ressalta-se a importância de estudos que priorizem a reutilização de água para aplicações nas quais a potabilidade não seja um requisito fundamental.

Até o momento da publicação da NBR15900: 2009, não havia antecedentes que garantissem a viabilidade de se utilizar água de reúso como água de amassamento de concreto. Todavia, este trabalho demonstrou a possibilidade do uso desse tipo de água na fabricação de peças de concreto para pavimentação.

Agradecimentos

O projeto contou com o apoio do SAE/UNICAMP, na forma de bolsa de Iniciação Científica.

\footnotetext{
${ }^{1}$ Associação Brasileira De Normas Técnicas. NBR 15900-1:2009 - Água para amassamento do concreto Parte 1: Requisitos. São Paulo, 2009. 2 Associação Brasileira De Normas Técnicas. NBR 9781:2013-Peças de concreto para pavimentação - Especificação e métodos de ensaio. São Paulo, 2013.

${ }^{3}$ De Oliveira Cruz, L. M.; Stefanutti, R.; Coraucci Filho, B.; Tonetti, A. L. Coconut shells as filling material for anaerobic filters. SpringerPlus, v. 2 , p. 655,2013

${ }^{4}$ Tonetti, A. L.; Coraucci Filho, B.; Nicolau, C. E.; Barbosa, M.; Tonon, D. Tratamento de esgoto e produção de água de reúso com o emprego de filtros de areia. Engenharia Sanitária e Ambiental, v. 17, p. 287-294, 2012.

Marinho, L. E. O.; Tonetti, A. L.; Stefanutti, R.; Coraucci Filho, B. Application of Reclaimed Wastewater in the Irrigation of Rosebushes. Water, Air and Soil Pollution (Dordrecht. Online), v. 224, p. 1669, 2013 ${ }^{6}$ Marinho, L. E. O.; Coraucci Filho, B.; Roston, D. M.; Stefanutti, R.; Tonetti, A. L. Evaluation of the Productivity of Irrigated Eucalyptus grandis with Reclaimed Wastewater and Effects on Soil. Water, Air and Soil Pollution (Print), v. 225, p. 1830, 2014

Ministério Da Saúde. Portaria No 2914, de 12 de dezembro de 2011. ${ }^{8}$ Conselho Nacional Do Meio Ambiente. Resolução $N^{o} 357$, de 17 de março de 2005.

${ }^{9}$ Conselho Nacional Do Meio Ambiente. Resolução $N^{o} 274$, de 29 de novembro de 2000

${ }^{10}$ Montgomery, D.C. Design and Analysis of Experiments, John Wiley \&
} Sons Inc., 8th edition, New York, NY, USA, 2013 